\title{
Estimation of technical efficiency of black cumin (Nigella sativa L.) farming in northwest Ethiopia: a stochastic frontier approach
}

\author{
Abebe Birara Dessie ${ }^{* *} \mathbb{0}$, Tadie Mirie Abate ${ }^{1}$, Betelhem Tsedalu Adane ${ }^{1}$, Tiru Tesfa ${ }^{2}$ and Shegaw Getu ${ }^{2}$
}

*Correspondence:
a.birara@yahoo.com
1'Department
of Agricultural Economics,
College of Agriculture
and Environmental Science,
University of Gondar, P.O. BOX
196, Gondar, Ethiopia
Full list of author information
is available at the end of the
article

${ }^{*}$ Correspondence:

birara@yahoo.com

of Agricultural Economics,

College of Agriculture

Unironmental scienc

196, Gondar, Ethiopia article

\begin{abstract}
Ethiopia is one of the east African countries which produce and exports various spices to other countries. Black cumin (Nigella sativa L.) is an important stiff annual flowering plant which mainly grows by producers for its seeds. An increasing demand of black cumin seed and oil in local, national and international market for medicinal, consumption and commercial purpose makes the best alternative crop for small holder farmers in Ethiopia. In spite of its importance, not much has been done to improve its production and productivity in Ethiopia. Therefore, this research was designed to examining efficiency variations and factors influencing technical inefficiency levels of producers on black cumin production in northwest Ethiopia. Primary data were collected using a semi-structured questionnaire administered on 188 black cumin producers selected using systematic random sampling technique. Moreover, various data analysis methods such as descriptive statistics and stochastic frontier model were used for analyzing the data. The empirical result obtained by applying maximum likelihood estimate of stochastic frontier model revealed that seed $(p<0.01)$ labor $(p<0.05)$, chemical $(p<0.01)$ and land $(p<0.05)$ were significant input variables in determining black cumin production. The mean technical efficiency level of black cumin producer was generally low, about $53.1 \%$. The mean value of actual yield, potential yield and yield gap was $3.131,5.832$ and 2.701 quintals, respectively. Moreover, the result of stochastic frontier model together with the inefficiency parameters revealed that market price of black cumin $(p<0.01)$ and access of extension service $(p<0.1)$ were significant variables and positively influenced the efficiency levels of black cumin producers. Whereas age of producers $(p<0.05)$ and distance to farm plot $(p<0.01)$ negatively influenced the technical efficiency levels of black cumin producers. Therefore, the study recommends that adoption of latest agricultural technologies; development of institutions, agricultural extension services and infrastructure are advisable to improve the efficiency and commercial value of black cumin production.
\end{abstract}

Keywords: Black cumin, Efficiency, Stochastic frontier model, Production, Ethiopia

\section{Introduction}

In developing countries, larger sections of the populations are depends on agriculture sector. In Africa, there is abundance of resources and high potential of attracting investors and producers in various agricultural productions and emerging markets (Fiergbor 
2020). However, the sector's production, productivity and efficiency status is low in most African countries including Ethiopia (FAO and WFP 2012). Therefore, adopting of any production technologies are important tool for reducing poverty and production cost (Kassie et al. 2011), smoothing variation and shocks of any country's aggregate output and economy (Ogun 2020) and increase a source of diversified income (Maertens and Barrett 2012). A spice is a dried seed, fruit, root, bark or vegetative agricultural product which produced for consumption and commercial purpose (Dessie et al. 2019a), flavoring of foods, and sometimes as a preservative of food by killing and preventing the growth of some harmful bacteria (Tesfa et al. 2017; Spice Sector Strategy Coordinating Committee 2010). Figure 1 shows that the top nine spice producer countries in the world were India which produces about 1,939,000 tonnes followed by Turkey (199,018 tonnes), Bangladesh (180,993 tonnes), China (113,359 tonnes), Indonesia (110,387 tonnes), Pakistan (73,472 tonnes) and Ethiopia, about 36,754 tonnes (FAOSTAT 2019).

Ethiopia is a country with different and favorable agro ecological zones for production of various spices, vegetables and crops (Dessie et al. 2019a, b). The country grows more than 14 spice varieties particularly black cumin, white cumin, pepper, paprika, turmeric, fenugreek, garlic, korarima, coriander, ginger, cardamom, and basil for consumption and commercial purposes (Etissa 1998; Girma et al. 2008; Tesfa et al. 2017; NABC 2019; Dessie et al. 2019a, b). Similarly, Ethiopia is one of the top spice producer and consumer countries (Vijayalaxmi and Sreepada 2014) and ranking first and seventh in Africa and global spice production, respectively (FAOSTAT 2019). Moreover, Ethiopian societies use spice products for various purposes such as to flavor bread, butter, meat, soups, vegetables, and to medicines and perfumes (International Trade Centre 2010; Tesfa et al. 2017).

Cumin (Cuminum cyminum) is an important spice type which is mainly cultivated for the purpose of flavoring vegetables, pickles, soups, sauces, cheese and for pleasant

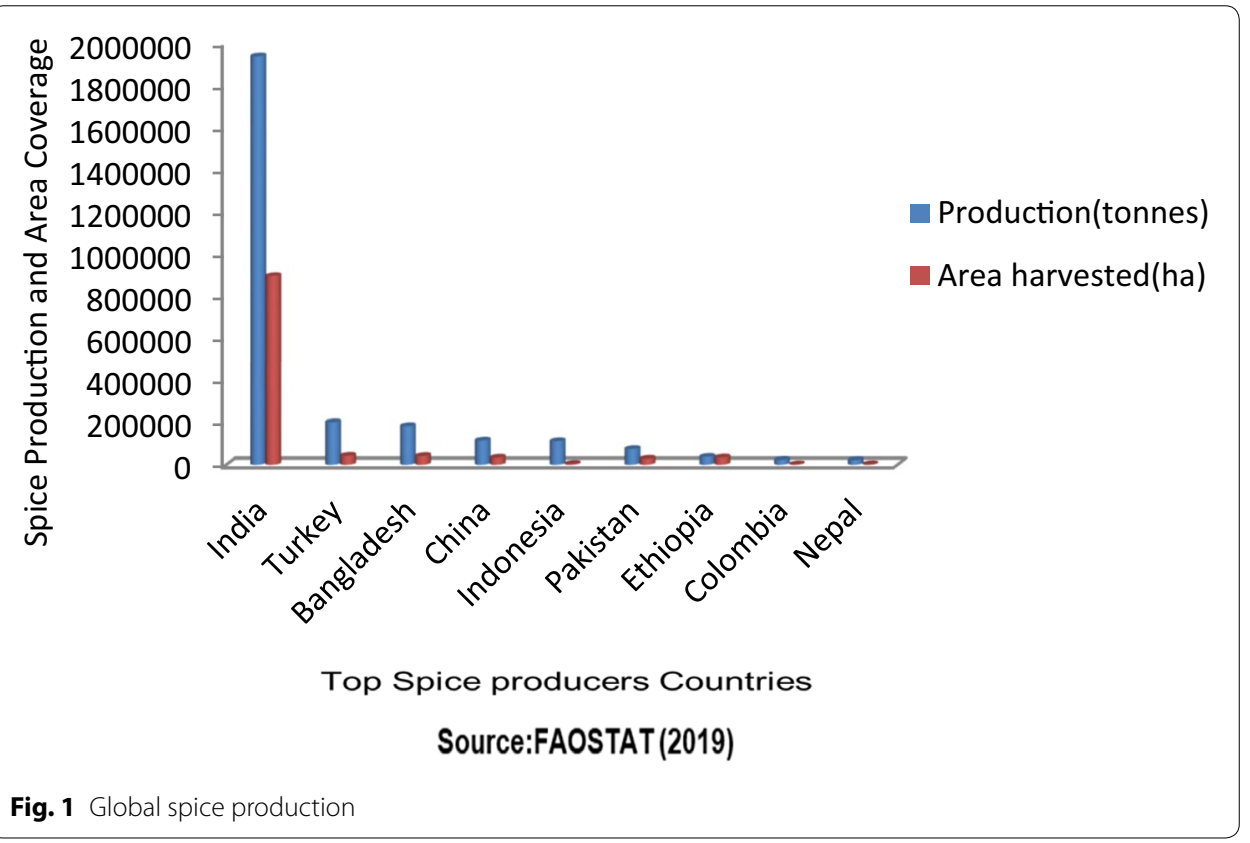


aroma (Verma and Kumar 2015; Atta 2003; Takruri and Dameh 1998). About $70 \%$ of the world cumin production is produced by India and consumed by China, Indonesia, Singapore, Malaysia, Bangladesh, Nepal and India itself (Spices Board India 2009). Similarly, cumin has two best varieties such as white and black. In 2012, the global cumin production was estimated to be 300,000 tonnes, with India contributing about 210,000 tonnes cumin output (Sonke and Lisanne 2013).

Black cumin (Nigella sativa L.) is a flowering plant which belongs to the family Ranunculaceae (buttercup). The scientific term of Nigella sativa has other synonyms such as Nigella damascena, Nigella ciliaris, Nigella arvensis and Nigella hispanica. Nigella sativa is also known by its vernacular names such as black cumin (English), Tikur azimude (Ethiopia), Cheveux de vénus (France), Jinten hitam (Indonesia), Kanauji (Punjabi), Habbet as-suda (Arabic), Jintan hitam (Malaysia), Hak jung chou (Chinese, Cantonese) and Thian dam in Thailand (Alemu 2016; Burits and Bucar 2000). Literatures also revealed that black cumin is native to the Mediterranean region but currently, it is cultivated in different parts of the world including Ethiopia. In recent times, many medicinal values have been accredited to black cumin seeds and its oil.

In Ethiopia, black cumin is one of the most important spice types which are mainly produced to flavor foods, preparation of oil for perfumes and medicinal purpose, source of income, crop diversification, and export purposes (Anshiso and Teshome 2018; Teshome and Anshiso 2019). It is also used for reducing the hotness of pepper powder in the country (Edwards et al. 2003). Therefore, black cumin production can be increased either using modern agricultural technologies or improving the efficiency of inputs with existing technologies. Moreover, Kopp (1981) defined efficiency as the ability to produce the maximum amount of outputs using the existing levels of inputs and technologies.

In the country, the annual production of black cumin was 18,000 metric tons in 2014/2015 crop production season (Ethiopian Investment Agency 2015). The national average productivity of black cumin was 0.79 tonnes/ha (Kifelew et al. 2017). The demand of black cumin seed and its oil has also been increasing both in Ethiopian local and national markets for consumption purpose. It is also the second important cash crop which is exported to international market next to ginger (Teshome and Anshiso 2019).

Even though the production and area coverage of black cumin have been increasing, its productivity is still very low in the country. Yosef (2008) revealed that the main factors influencing the production and productivity of black cumin were lack of improved seed, absence of recommended fertilizer rate; postharvest handling problem; lack of improved agriculture practices and extension system, marketing problems. In Ethiopia, the adoption of modern and intensive agricultural technologies such as the use of row planting, inorganic fertilizer and improved seeds was also very low (Chanyalew et al. 2010). Moreover, the production and productivity of cumin were influenced by various socio-economic, demographic, institutional and environmental factors (Teshome and Anshiso 2019; Nejad and Khorramabad 2011; Lindara et al. 2004).

In Ethiopia, the main black cumin producer regions are Amhara, Oromia, SNNP and Gambiella (Teshome and Anshiso 2019). Though there is the high potential in black cumin production in the country, how much to produce and when to produce, what are the efficiency levels of producers and which factors influence the technical efficiency 
levels of black cumin producers were hardly studied in the study area. Based on the above statement, the study was intended to empirically answer the following three key research questions: (1) Are the producers technically efficient in black cumin production? (2) What factors influence the technical efficiency levels of black cumin producers? (3) What are the comparison levels of potential and actual black cumin production in the study area? Therefore, studying the efficiency level of producers is imperative to determine the extent to raising black cumin production and productivity using the existing levels of inputs and technology. The findings from this study are believed to be helpful in reducing the information gap on black cumin and contributing to work better on input usage, production and marketing strategies for the benefit of producers, traders, government and ultimate consumers.

\section{Research methods}

\subsection{Description of study area}

The study was done in north Gondar zone but currently the zone divided into three zones namely west Gondar, central Gondar and north Gondar zone. The zone is located in the northwest of Ethiopia and $738 \mathrm{~km}$ far from the capital city of the country. The capital city of the zone is Gondar city which located at $12^{\circ} 35^{\prime} 60.00^{\prime \prime} \mathrm{N}$ latitude and $37^{\circ} 28^{\prime}$ $0.01^{\prime \prime} \mathrm{E}$ longitudes with mean altitude of $2133 \mathrm{~m}$ above sea level. In the zone, the main sources of livelihood for households are crop production, vegetable production, animal production, bee keeping and spice production particularly pepper, ginger, white and black cumin. The low land of the zone is dominated by semi-arid natural forest. In the zone, $51 \%$ and $49 \%$ of population are men and women, respectively (Dessie et al. 2019a,

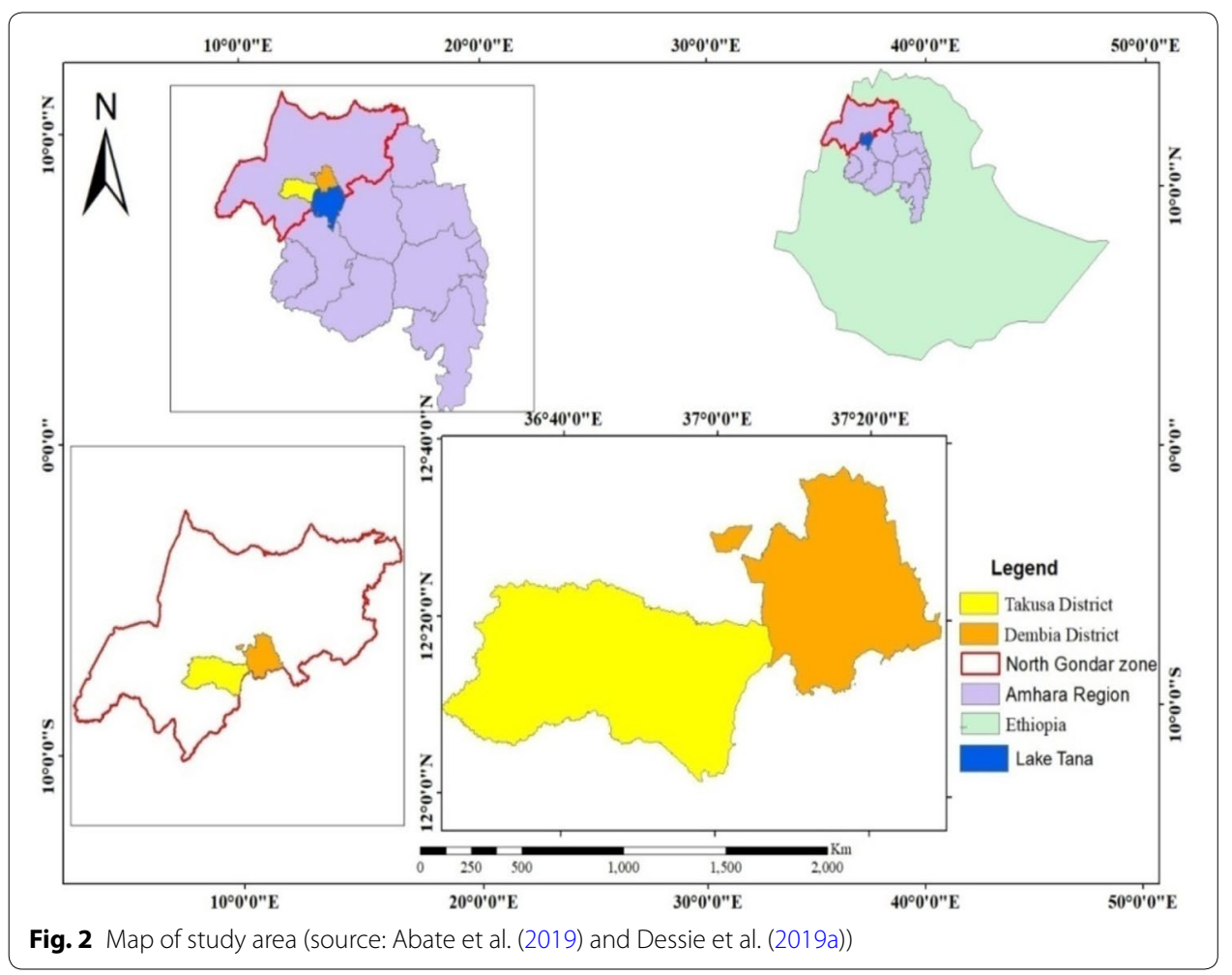


b; Abate et al. 2019). The survey was done in 2019 cropping season on two large black cumin producer districts of the zone specifically, Takusa and Dembia districts (Fig. 2).

\subsection{Sampling technique and sample size determination}

A multi-stage sampling technique was used to select sample producers. In the firststage, two main black cumin producer districts namely, Takusa and Demebia district, were selected using purposive sampling technique due to its high potential black cumin production. In the second stage, nine main black cumin producer kebeles/rural villages/namely, Mekonta, Chemera, Seravadelo, Guarhie, Tezeba, Darna, Banbaro, Jangua and Gebaba-salge, were also selected using purposive sampling technique due to the best producers' experience in production and marketing of black cumin output. In the third stage, 188 sampled black cumin producers were selected using a systematic simple random sampling technique proportionate to size sampling methodology following (Cochran 1977).

$$
n=\frac{Z^{2} p q}{e^{2}}
$$

where $n$ is the sample size; $Z$ is the confidence level $(Z=1.96) ; p$ is the proportion of population containing major interest $(p=0.5$ and $q=1-p)$ and $e$ is allowable error $(e=0.072)$.

\subsection{Methods of data collection}

In this study, both primary and secondary data were collected from various sources. The main primary data collection methods were semi-structured questionnaires and key informant's interviews. Moreover, to enrich the investigation secondary data were collected from various sources. The interview schedule which consists of semi-structured questions was prepared in English and translated into local language to collect information on socio-economic, demographic and institutional characteristics of households. Furthermore, the questionnaire was pre-tested using pilot survey, and the necessary amendment was made before the actual survey. Finally, semi-structured interviews were administered on 188 black cumin producers.

\subsection{Methods of data analysis and model specification}

Various data analysis methods such as descriptive statistics and econometric model were used to analyze the data. Descriptive statistics such as means, frequencies, and percentages were used to examine the socio-economic, institutional and demographic characteristics of sampled producers.

In addition, the most common production functional model such as Cobb-Douglas function was used to measure the physical relationship between production inputs and black cumin output. As compared to transcendental logarithmic (translog) function, the Cobb-Douglas production function is the simplest, less susceptible to multicollinearity problem among explanatory variables and provides coefficients of a plausible sign and magnitude (O'Neill et al. 1999). Moreover, the Cobb-Douglas has been widely used in 
many empirical studies particularly those related to developing countries for farm efficiency analysis (Bravo-Ureta and Pinheiro 1997).

The general form of Cobb-Douglas production function is given in Eq. (2).

$$
Y=F\left(X_{i} \beta\right) \exp \left(V_{i}-U_{i}\right), \text { where } i=1,2,3 \ldots 188 .
$$

Using a linear representation, the empirical production function to be estimated as follows in Eq. (3):

$$
\ln Y_{i}=\beta_{0}+\beta_{1} \ln \mathrm{lab}+\beta_{2} \ln \text { land }+\beta_{3} \ln \text { seed }+\beta_{4} \ln \text { oxen }+\beta_{5} \ln \text { chemical }+\beta_{6} \ln \text { fert }+v_{i}-u_{i},
$$

where $Y_{i}$ is the production of black cumin yield of $i$ th producer, $X_{i}$ a vector of inputs used by the $i$ th producer, $\beta$ a vector of unknown parameters, and $v_{i}$ a random variable which is assumed to be $N\left(0, \sigma_{v_{i}}^{2}\right)$ and independent of the $u_{i}$ which is nonnegative random variable assumed to account for technical inefficiency in black cumin production.

The farm-specific technical efficiency (TE) is also defined in terms of observed output $\left(Y_{i}\right)$ to the corresponding frontier output $\left(Y_{i}^{*}\right)$ using the available technology to be estimated in Eq. (4).

$$
\mathrm{TE}_{i}=\frac{Y_{i}}{Y_{i}^{*}}=\frac{\text { Actual yield }}{\text { Potential yield }}
$$

Technical efficiency takes value on interval $(0,1)$, where 1 indicates a fully efficient farm.

In this study, the yield gap $\left(\mathrm{YG}_{i}\right)$ of $i$ th producer in black cumin production is the difference between potential yield $\left(\mathrm{PY}_{i}\right)$ and actual yield $\left(\mathrm{AY}_{i}\right)$ and estimated in Eq. (5) as follows:

$$
\mathrm{YG}_{i}=\mathrm{PY}_{i}-\mathrm{AY}_{i} .
$$

All parameters of the stochastic frontier and inefficiency effect model were estimated in a single-stage maximum likelihood (ML) method through Frontier 4.1 software following (Coelli 1996). Therefore, a stochastic frontier approach was used to estimate the technical efficiency levels of cumin producers and to differentiate inefficiency from deviations that are caused from factors beyond the control of producers estimated in Eq. (6) as follows:

$$
\begin{aligned}
\mu_{i}= & \delta_{0}+\delta_{1 i}\left(\text { Age }_{i}\right)+\delta_{2 i}\left(\text { Educ }_{i}\right)+\delta_{3 i}\left(\text { TLU }_{i}\right)+\delta_{4 i}\left(\text { Landzize }_{i}\right)+\delta_{5 i}\left(\text { Market price }_{i}\right) \\
& +\delta_{6 i}\left(\text { Land fragementation }_{i}\right)+\delta_{7 i}\left(\text { Soil fertility }_{i}\right)+\delta_{8 i}\left(\text { extension acess }_{i}\right)+\delta_{9 i}\left(\text { distance to farmplot }_{i}\right),
\end{aligned}
$$

where $\mu_{i}$ is the technical inefficiency indices; the subscript $i$ indicates the $i$ th household in the sample $(i=1, \ldots, 188)$; and $\delta_{0}, \delta_{1 i}, \ldots, \delta_{9 i}$ are parameters to be estimated.

\section{Results and discussion}

\subsection{Demographic and socio-economic characteristics of households}

In the study area, about $96.28 \%$ and $3.72 \%$ sample households were male and female headed, respectively. Similarly, about $57.45 \%$ and $42.55 \%$ of sample household were illiterate and literate, respectively. Moreover, about $61.17 \%$ and $46.81 \%$ of producers 
Table 1 Mean and proportion households' characteristics $(N=188)$

\begin{tabular}{llll}
\hline Continuous variables & Mean & \multicolumn{2}{l}{ Standard deviation } \\
\hline Age in years & 48.02 & 0.77 & \\
Family size in AE & 6.20 & 0.16 & \\
Land size allotted to black cumin in ha & 0.40 & 0.20 & \\
Output in quintals & 3.13 & 0.15 & \\
Market price in ETB/Qt & 3608.12 & 53.47 & Percentage \\
Distance to development center in km & 3.37 & 0.13 & 47.34 \\
Distance to the nearest market in km & 4.40 & 0.22 & 52.66 \\
\hline Dummy variable & Response & Frequency & 96.28 \\
\hline Extension service & Yes & 89 & 3.72 \\
Sex & No & 99 & 57.45 \\
Education status & Male & 181 & 42.55 \\
& Female & 7 & 61.17 \\
Market information & Illiterate & 108 & 38.83 \\
\hline
\end{tabular}

Table 2 Black cumin yield gap due to technical inefficiency

\begin{tabular}{llllr}
\hline Variable & Mean & Std. dev. & Min & Max \\
\hline Actual yield (quintal/0.4 ha) & 3.132 & 2.092 & 0.800 & 20.000 \\
TE & 0.531 & 0.212 & 0.140 & 0.935 \\
Potential yield (quintal/0.4 ha) & 5.832 & 2.399 & 2.767 & 23.625 \\
Yield gap (quintal/0.4 ha) & 2.701 & 1.622 & 0.519 & 10.392 \\
\hline
\end{tabular}

were got market information and extension service, respectively (Table 1). The result also revealed that the mean age of households, family size, land size allotted to black cumin, distance to development center, output, market distance, and market price were 48.02 years, 6.2 in AE, $0.4 \mathrm{ha}, 3.37 \mathrm{~km}, 7.825 \mathrm{Qt} / \mathrm{ha}, 4.4 \mathrm{~km}$, and $3608.12 \mathrm{ETB} /$ Qt, respectively (Table 1). The mean age 48.02 years implies majority of the black cumin producers are still in their active age and thus expected to be productive. This result is in line with the findings of Dessie et al. (2019a, b) and Wassihun et al. (2019) confirmed that the mean age of red pepper and potato producers in northwest Ethiopia was 48.31 and 46.69 years, respectively.

\subsection{Black cumin efficiency scores and yield gap due to inefficiency}

The result in Table 2 shows the mean technical inefficiency was $46.9 \%$ which caused 2.701 quintal yield gap of black cumin which is equivalent to $6.753 \mathrm{Qt}$ per ha. The result also shows the mean value of the actual output and the potential yield of black cumin was 3.132 and 5.832 quintals, respectively. This implies that sample producers in study area were producing on average 2.701 quintal of black cumin yield lower than their potential yield. Similarly, the result indicated that in the short run there is a room to improving efficiency level of producers and yield of black cumin by 2.701 


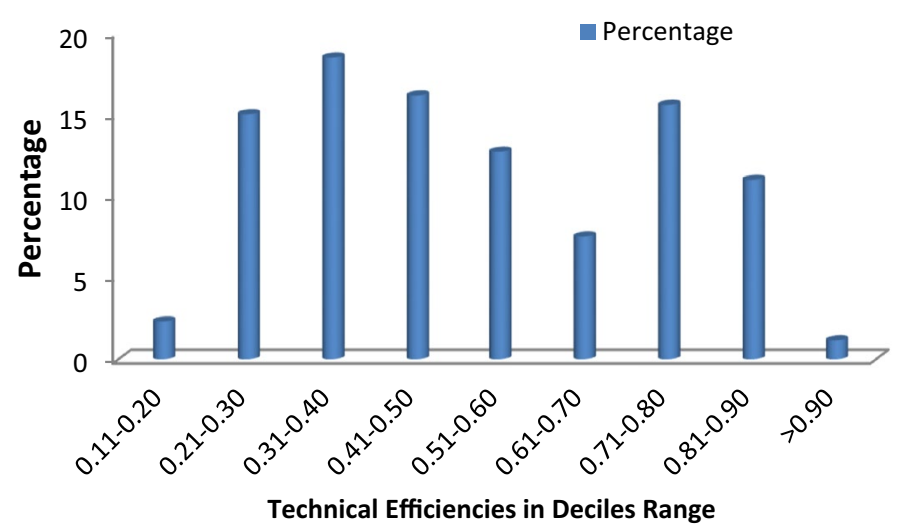

Fig. 3 Frequency distribution of technical efficiency

Table 3 Generalized likelihood ratio test of hypotheses for model and parameters

\begin{tabular}{lcccl}
\hline Null hypothesis & Degree of freedom & LR & $\boldsymbol{x}^{\mathbf{2}}$ value & Decision \\
\hline$H_{0}: \gamma=0$ & 1 & 72.66 & $3.84^{* *}$ & Rejected \\
$H_{0}: \beta_{7}=\cdots=\beta_{27}=0$ & 21 & 30.53 & $32.67^{* *}$ & Not rejected \\
$H_{0}: \delta_{0}=\cdots=\delta_{9}$ & 9 & 72.66 & $16.92^{* *}$ & Rejected \\
\hline
\end{tabular}

**Statistically significant at $5 \%$

quintal using the existing levels of input and technology (Table 2). This finding is in line with Abate et al. (2019) who found that the mean technical inefficiency and yield gap of red pepper in northwest Ethiopia were $21.2 \%$ and $191.452 \mathrm{~kg}$, respectively. Similarly, Wassihun et al. (2019) confirmed that the mean technical inefficiency of producers in potato production was $54 \%$ in northwest Ethiopia.

The result in Fig. 3 shows the frequency distribution of technical efficiency levels of black cumin producers. In the study area, the technical efficiency levels of black cumin producers vary from one to another. The efficiency levels of growers range from 0.140 to 0.935 . The majority of cumin producers $(18.49 \%)$ have a lower technical efficiency score (between 0.31 and 0.40). The result in Fig. 3 also revealed that the distribution of the TE scores is skewed to the left implying less technically efficient. More than $16.18 \%$ of sampled producers have also a TE score between 0.41 and 0.50 . The frequency distribution of efficiency indexes indicates there is a high technical efficiency variation among producers. Therefore, the presence of technical inefficiencies could be eliminated by implementing the practice of technically efficient black cumin producers in the study area. This finding is confirmed with Lindara et al. (2004) endorsed that the mean technical inefficiency of large spice producers and small spice producers in Sir Lanka was $20.57 \%$ and $10.07 \%$, respectively.

\subsection{Estimation of production function and hypothesis tests}

The stochastic production frontier was applied using the maximum likelihood estimation procedure using Frontier 4.1 computer program. Prior to model estimation, all the hypotheses (assumption of stochastic frontier) were tested using generalized likelihood 
ratio (LR). The LR test was made to decide whether the traditional average production function (OLS) best fits the data set as compared to the stochastic frontier model (SFM). The test was carried out by estimating the stochastic frontier production function and conducting a likelihood ratio test assuming the null hypothesis of no technical inefficiency $\left(H_{0}: \gamma=0\right)$. The likelihood ratio test statistics was 72.66 . This value exceeds the critical $x^{2}(5 \%, 1)$ value of 3.84 at $5 \%$ level of significance (Table 3$)$. The result shows the null hypothesis was rejected and implying there is statistically significant inefficiency in the data. This also implies that stochastic frontier production function was an adequate representation of the data.

Likewise, the LR statistical test was estimated for the selection of the appropriate functional form (Cobb-Douglas versus Translog production function). The calculated likelihood ratio (LR) is equal to 30.53 and the critical value of $x^{2}$ at 21 degrees of freedom and 5\% significance level is 32.67 (Table 3). Thus, the null hypothesis that all coefficients of the interaction terms in Translog specification are equal to zero was not rejected. This implies that the Cobb-Douglas functional form sufficiently represents the data. Hence, the Cobb-Douglas functional form was used to estimate the technical efficiency levels of the black cumin producers in the study area.

Moreover, LR statistical test was estimated to test the third assumption. Farm-level technical inefficiencies are not affected by the socio-economic variables included in the inefficiency model $\left(H_{0}: \delta_{0}=\delta_{1}=\cdots=\delta_{9}=0\right)$. The calculated LR value of 55.59 was greater than the critical value of 16.92 at 9 degrees of freedom. The result shows that the null hypothesis $\left(H_{0}\right)$ that explanatory variables are simultaneously equal to zero was rejected at $5 \%$ significance level. This implies that there is a room to improving black cumin output by identifying those institutional, socio-economic and farmspecific factors causing this variation.

Furthermore, the degree of multicollinearity among the explanatory variables has been tested using variance inflation factor (VIF) test for continuous variables and contingency coefficient (CC) test for dummy variables. Therefore, the post estimation

Table 4 OLS and ML estimate of production frontier for black cumin producers

\begin{tabular}{|c|c|c|c|c|c|}
\hline \multirow[t]{2}{*}{ Variables } & \multirow[t]{2}{*}{ Parameters } & \multicolumn{2}{|c|}{$\begin{array}{l}\text { Ordinary least square } \\
\text { estimates }\end{array}$} & \multicolumn{2}{|c|}{$\begin{array}{l}\text { Maximum likelihood } \\
\text { estimates }\end{array}$} \\
\hline & & Coefficient & Std. err & Coefficient & Std. err \\
\hline Constant & $\beta_{0}$ & $0.547^{*}$ & 0.324 & $0.683^{* *}$ & 0.345 \\
\hline Lnseed & $\beta_{1}$ & $0.190^{* *}$ & 0.080 & $0.332^{* * *}$ & 0.097 \\
\hline LnNPS & $\beta_{2}$ & 0.032 & 0.026 & -0.043 & 0.031 \\
\hline Lnland & $\beta_{3}$ & $0.240^{* *}$ & 0.097 & $0.227^{* *}$ & 0.103 \\
\hline LnChemical & $\beta_{4}$ & $0.251^{* * *}$ & 0.047 & $0.185^{* * *}$ & 0.049 \\
\hline LnOxen & $\beta_{5}$ & 0.049 & 0.114 & 0.052 & 0.112 \\
\hline LnLabor & $\beta_{6}$ & $0.159^{*}$ & 0.085 & $0.202^{* *}$ & 0.080 \\
\hline Sigma-squared $\left(\sigma^{2}\right)$ & & & & $0.211^{* * *}$ & 0.036 \\
\hline Gamma $(\gamma)$ & & & & $0.849^{* * *}$ & 0.076 \\
\hline Return to scale & & & & 0.946 & \\
\hline Log likelihood function & & -127.582 & & -91.247 & \\
\hline Total sample size & & 188 & & 188 & \\
\hline
\end{tabular}

***, ${ }^{* *}$ and $*$ are statistically significant at $1 \%, 5 \%$ and $10 \%$, respectively 
result shows the value of variance inflation factor and the contingency coefficient were less than 10 and 0.75 , respectively. This implies that the data have not multicollinearity problems.

One of the attractive features of the Cobb-Douglas production functional form is the direct interpretation of its parametric coefficients with respect to the level of input used. This feature allows researchers to evaluate the potential effects of changes in the amount of production input used on the amount of output to be produced.

The result of stochastic frontier model in Table 4 revealed that four input variables such as seed, land, chemical (herbicide and pesticides), and labor positively and significantly influenced the amount of black cumin production. This implies that as the amount of seed, size of land, amount of chemical, and number of labor increased by $1 \%$, the amount of black cumin production also increased by $0.332 \%, 0.227 \%, 0.185 \%$, and $0.202 \%$, respectively (Table 4). This study is in line with recent studies of Abate et al. (2019), Wassihun et al. (2019), Tefaye and Beshir (2014)and Lindara et al. (2004); they revealed that the amount of input usage has a direct implication on crop and spice production.

The value of sigma-squared $\left(\sigma^{2}\right)$ for frontier of black cumin output was 0.211 and statistical significant at $1 \%$ level. The significant value indicates the goodness of fit of the specified assumption of the composite error terms distribution (Ahmed 2014; Kifle et al. 2017; Abate et al. 2019). The estimated value of gamma was also 0.849 . This implies $84.9 \%$ of total variation in black cumin output was due to technical inefficiency of producers.

Moreover, the return to scale of this study was estimated to be $0.946 \%$ implying decreasing returns to scale. This implies that a $1 \%$ increase in all inputs proportionally would increase the total production of black cumin by less than $1 \%$. This result is in line with the findings of Abate et al. (2019) who found that the estimated return to scale was $0.983 \%$ in red pepper technical efficiency farming systems of northwest Ethiopia. Alemu et al. (2009) also endorsed that the estimated return to scale was $0.962 \%$, implying decreasing return to scale across technical efficiency farming systems in Ethiopia.

\subsection{Determinants of technical inefficiency of black cumin producers}

Age of producer was statistically significant $(p<0.05)$ and positively influences the technical inefficiency of black cumin production at $5 \%$ of level of significance (Table 5 ). The

Table 5 Maximum likelihood estimates of technical inefficiency determinants

\begin{tabular}{llccr}
\hline Variables & Parameters & Coefficient & Std. err & $T$-ratio \\
\hline Constant & $\delta_{0}$ & $11.935^{* * *}$ & 2.497 & 4.779 \\
Age & $\delta_{1}$ & $0.010^{* *}$ & 0.004 & 2.299 \\
Education status & $\delta_{2}$ & -0.134 & 0.108 & -1.242 \\
Tropical livestock unit & $\delta_{3}$ & 0.002 & 0.016 & 0.137 \\
Land size allotted to cumin & $\delta_{4}$ & 0.073 & 0.276 & 0.265 \\
Market price & $\delta_{5}$ & $-1.440^{* * *}$ & 0.312 & -4.611 \\
Land fragmentation & $\delta_{6}$ & -0.024 & 0.133 & -0.180 \\
Soil fertility & $\delta_{7}$ & -0.121 & 0.175 & -0.689 \\
Extension service & $\delta_{8}$ & $-0.274^{*}$ & 0.145 & -1.887 \\
Distance to farm plot & $\delta_{9}$ & $0.074^{* * *}$ & 0.026 & 2.846 \\
Log likelihood function & & -91.247 & & \\
\hline
\end{tabular}

***, ** and * are statistically significant at $1 \%, 5 \%$ and $10 \%$, respectively 
significantly, positive relationship between age and technical inefficiency of black cumin production implies that older producers are more technical inefficient than younger producers. This can be explained by the fact that as a producer become more aged, it becomes difficult for proper utilization of inputs and adoption of latest technologies on their farms. Likewise, younger producers will be more energetic, active and can make well-thought decisions in farming system and as a result, their efficiency level in black cumin production increases. This result is consistent with the recent findings (Kinde Teshome 2005; Dolisca and Jolly 2008; Amodu et al. 2011; Hailemaraim 2015; Haile et al. 2018; Dessie et al. 2019a, b; Begum et al. 2019).

Market price of black cumin was statistically significant $(p<0.01)$ and negatively influences the technical inefficiency of black cumin production at $1 \%$ level of significance. The negative relationship between market price and technical inefficiency implies that the technical inefficiency level of producers decreased as the commercial value of black cumin increases.

Extension service was statistically significant $(p<0.1)$ and negatively influences the technical inefficiency of black cumin production at $10 \%$ level of significance (Table 5). The negative relationship between extension service and technical inefficiency implies farmers who got extension advice and training was less technically inefficient than those who did not accessed. It also implies that extension advice and training improve both farmers' ability of choosing appropriate and least cost combination of production inputs and ability to producing the optimum amount of yield using such inputs. Moreover, agricultural extension services are supposed to improve the efficiency level by closing the gap between knowledge of farmers and the existing technological and technical knowledge. This finding is consistent with Gelaw and Bezabih (2004), Begum et al. (2019) and Abate et al. (2019); they endorsed that a well-managed extension service is expected to improve farmers' efficiency level.

Distance to farm plot was statistically significant $(p<0.01)$ and positively influences the technical inefficiency of black cumin production at $1 \%$ level of significance (Table 5). The significant and positive relationship between farm plot distance and technical inefficiency implies that as the distance to farm plot increases, the technical inefficiency level of black cumin producers also increases. This could be attributed to the fact that the farther the farm plot from producer's residence, the greater would be the cost of transport and poorly managed their farm activities in turn exposed for technical inefficiency.

\subsection{Conclusion and recommendations}

Black cumin is an important spice crop which is mainly produced by Ethiopian small holder farmers for medicinal value, commercial purpose, and flavorings of food items. However, information on production, productivity and technical efficiency levels of black cumin is limited in the country. Therefore, the main aim of this study was to examine the efficiency variations and factors influencing technical efficiency levels of producers on black cumin production in northwest Ethiopia. Combinations of data analysis methods such as descriptive and econometric analysis were used to analyze the data. The finding revealed that the mean technical efficiency level of black cumin producers was low. It also shows there is large yield gap between actual and potential yield of black cumin in the study area. The study implies that there is an opportunity of increasing the 
levels of black cumin production and productivity by improving the technical efficiency levels of producers using the existing levels of inputs. The return to scale in the study area was decreasing, implying as a black cumin producer uses one unit of input the total black cumin production proportionally increases by less than one unit. The maximum likelihood estimate of stochastic frontier model revealed that important production input variables such as seed, land, chemical (herbicide and pesticides), and labor positively and significantly influenced the black cumin production. The positive coefficient of parameters indicates that as the producers increased the input usage by $1 \%$, the levels of black cumin production also increase by less than $1 \%$. Moreover, the result of stochastic frontier model together with the inefficiency parameters shows market price of black cumin output and extension service were decreased inefficiency whereas age of producers and distance to farm plot were increased inefficiency levels. Based on the findings, the inefficiency levels in black cumin farming can be reduced significantly by strengthening extension services, local and national marketing institutions and providing intensive training to black cumin producers. Generally, for holistic black cumin production and marketing, there should be strong linkage and integration among producers, university centers, agricultural research centers, development agents and policy makers.

\begin{abstract}
Abbreviations
AY: Actual yield; PY: Potential yield; YG: Yield gap; CSA: Central Statistical Agency; e: Error; ETB: Ethiopian Birr; FAO: Food and Agriculture Organization; Ho: Null hypothesis; Ha: Alternative hypothesis; LR: Log likelihood ratio; ML: Maximum likelihood; NABC: Netherlands-Africa Business Center; $n$ : Sample size; OLS: Ordinary least square; SFM: Stochastic Frontier model; SNNPS: Southern Nation and Nationality's People; Qt: Quintal; TE: Technical efficiency; Z: Confidence level; VIF: Variance inflation factor; CC: Contingency coefficient; WFP: World Food Program.
\end{abstract}

\title{
Acknowledgements
}

The author would like to thank the University of Gondar since financial support for this research was obtained from this institution. Moreover, we thank the data respondents, enumerators and district experts for their valuable response during data collection process.

\section{Authors' contributions}

All authors read and approved the final manuscript.

Funding

Not applicable.

Availability of data and materials

The author wants to declare that they can submit the data at any time based on publisher's request. The datasets used and/or analyzed during the current study will be available from the author on reasonable request.

\section{Ethics approval and consent to participate}

Ethical clearance letters were collected from University of Gondar research and community service directorate and North Gondar Zone administrative office to care for both the study participants and the researchers. During survey, official letters were written for each District and kebele/villages/informed verbal consent was obtained from each client, and confidentiality was maintained by giving codes for each respondent rather than recording their name. Study participants were informed that clients have a full right to discontinue or refuse to participate in the study. Hence, all participants throughout the research, including survey households, enumerators, the supervisors and key informants, were fully informed of the objectives of the study. They were approached friendly in free moods until the end of this research.

\section{Consent for publication}

Not applicable.

\section{Competing interests}

The authors declare that they have no competing interests.

\section{Author details}

${ }^{1}$ Department of Agricultural Economics, College of Agriculture and Environmental Science, University of Gondar, P.O. BOX 196, Gondar, Ethiopia. ${ }^{2}$ Department of Horticulture, College of Agriculture and Environmental Science, University of Gondar, Gondar, Ethiopia.

Received: 10 October 2019 Revised: 25 January 2020 Accepted: 15 February 2020

Published online: 25 February 2020 


\section{References}

Abate TM, Dessie AB, Mekie TM (2019) Technical efficiency of smallholder farmers in red pepper production in North Gondar zone Amhara regional state, Ethiopia. J Econ Struc 8(1):18

Ahmed MH (2014) Technical efficiency of maize producing farmers in Arsi Negelle, central rift valley of Ethiopia: stochastic frontier approach. Agric For/Poljoprivreda i Sumarstvo 60(1):157

Alemu B (2016) Extraction, characterization and optimization of essential oil from Ethiopian black cumin seed varieties by solvent extraction. M. Sc. thesis presented to Institute of Technology, Addis Abeba University, Ethiopia

Alemu BA, Nuppenau EA, Boland H (2009) Technical efficiency of farming systems across agro-ecological zones in Ethiopia: an application of stochastic frontier analysis. Agric J 4(4):202-207

Amodu MY, Owolabi JO, Adeola SS (2011) Resource use efficiency in part-time food crop production: the stochastic frontier approach. Nigerian J Basic Appl Sci 19(1):102

Anshiso D, Teshome W (2018) Economic Value of Black Cumin (Nigella sativa L.) conservation at bale zone of oromia region, Ethiopia. Am J Bus 6(4):104-109

Atta MB (2003) Some characteristics of Nigella (Nigella sativa L.) seed cultivated in Egypt and its lipid profile. Food Chem 83(1):63-68

Begum MEA, Miah MM, Rashid MA, Hossain MI (2019) Factors affecting the technical efficiency of turmeric farmers in the slash and burn areas of Bangladesh. Agrofor Syst 93(6):2205-2212

Bravo-Ureta BE, Pinheiro AE (1997) Technical, economic, and allocative efficiency in peasant farming: evidence from the Dominican Republic. Dev Econ 35(1):48-67

Burits M, Bucar F (2000) Antioxidant activity of Nigella sativa essential oil. Phytother Res 14(5):323-328

Chanyalew D, Adenew B, Mellor J (2010) Ethiopia's agricultural sector policy and investment framework (PIF) (20102020), Draft final report. Federal Democratic Republic of Ethiopia, Ministry of Agriculture and Rural Development. Addis Ababa

Cochran WG (1977) Sampling techniques, 3rd edn. Wiley, New York

Coelli TJ (1996) A guide to FRONTIER version 4.1: a computer program for frontier production function estimation. Centre for Efficiency and Productivity Analysis Working Paper, 96(07)

Dessie AB, Koye TD, Koye AD, Abitew AA (2019a) Analysis of red pepper marketing: evidence from northwest Ethiopia. $J$ Econ Struct 8(1):24

Dessie AB, Abtew AA, Koye AD (2019b) Analysis of smallholder farmers' cooperation in eucalyptus woodlot production in Wegera District, Northern Ethiopia. Small-scale For 18:291-308

Dolisca F, Jolly CM (2008) Technical efficiency of traditional and non-traditional crop production: a case study from Haiti. World J Agric Sci 4(4):416-426

Edwards S, Nemomissa S, Hedberg I (2003) Flora of Ethiopia and eritrea. Addis Ababa University, The National Herbarium Ethiopian Investment Agency (2015) Investment opportunity Profile for Spice Processing in Ethiopia. 7: 8-14 Etissa E (1998) Research achievements and experiences

FAOSTAT (2019) Crop production in Africa. Retrieved 2019, August 21. Countries—Select All; Regions—Africa + (Total); Elements—Area and Production Quantity; Items—spice; Years—2014-2017. http://www.fao.org/faostat/en/\#data/QC/

Fiergbor DD (2020) An empirical studies into mutual funds in emerging markets; prospects for personal financial planning. Glob Econ Sci 1(1)

Food and Agricultural Organization (FAO), World Food Programme (WFP) (2012) Crop and food security assessment mission toEthiopia. Special Report of Food and Agriculture Organization and World Food Programme

Gelaw F, Bezabih E (2004) Analysis of technical efficiency of wheat production: a study in Machakel Woreda, Ethiopia. Ethop J Agric Econ. 7:2

Girma H, Digafe T, Edossa E, Belay Y, Weyessa G (2008) Spices research achievements. Ethiopian Institute of Agricultural Research Annual Report, pp 12-22

Haile K, Haji J, Tegegne B (2018) Technical efficiency of sorghum production: the case of smallholder farmers in Konso District, Southern Ethiopia. Agric Dev 3:1-15

Hailemaraim L (2015) Technical Efficiency in Tef Production: The Case of Bereh District, Oromia National Regional State, Ethiopia (Doctoral dissertation, Haramaya University)

International Trade Centre (2010) Spice Sub-sector Strategy for Ethiopia. Addis Ababa, Ethiopia

Lindara MJ. Johnsen KL, Gunatilake HM (2004) Technical efficiency in the spice based agroforestry sector in Matale, Sri Lanka. Noragric working paper No. 34

Kassie M, Shiferaw B, Muricho G (2011) Agricultural technology, crop income, and poverty alleviation in Uganda. World Dev 39(10):1784-1795

Kifelew H, Getachew W, Luleseged T, Mitiku H, Bekele D, Fikere D (2017) Seed Spices Production Guideline. Ethiopian institute of agricultural Research

Kifle D, Moti J, Belaineh L (2017) Economic efficiency of smallholder farmers in maize production in Bako Tibe District, Ethiopia. J Dev Country Stud 7(2):80-86

Kinde Teshome (2005). Analysis of Technical Efficiency of Maize Production. A Study in Assosa Woreda. M.Sc. Thesis, Haramaya University, Haramaya, Ethiopia

Kopp RJ (1981) The measurement of productive efficiency: a reconsideration. Q J Econ 96(3):477-503

Maertens A, Barrett CB (2012) Measuring social networks' effects on agricultural technology adoption. Am J Agric Econ 95(2):353-359

NABC (Netherlands-Africa Business Center). (2019). Factsheet spices, herbs and aromatics in Ethiopia. https://www.nabc. nl/uploads/content/files/Factsheet\%20ABSF\%20spices\%2C\%20herbs\%20an\%20aromatics.pdf

Nejad AR, Khorramabad I (2011) Productivity of cumin (Cuminum cyminum L.) as affected by irrigation levels and row spacing. Aust J Basic Appl Sci 5(3):151-157

Ogun O (2020) Business cycle drivers in an open economy. Glob Econ Sci 1(1):1-43

O’Neill S, Matthews A, Leavy A (1999) Farm technical efficiency and extension. Department of Economics, Trinity College, Dublin 
Sonke B, Lisanne H (2013) Value chain analysis: cumin seeds-intraregional trade saarc: Afghanistan and Pakistan to Sri Lanka and Bangladesh. Triodos Facet BV, The Netherlands

Spice Sector Strategy Coordinating Committee (2010) Spice Sub-Sector STRATEGY for ETHIOPIA, ACP Agricultural Commodities Programme. International Trade Centre (ITC), Division of Country Programmes (DCP), Export Strategy

Spices Board India (2009) Spices Board Statistics. Kochi, India

Takruri HR, Dameh MA (1998) Study of the nutritional value of black cumin seeds (Nigella sativa L). J Sci Food Agric 76(3):404-410

Tefaye W, Beshir H (2014) Determinants of technical efficiency in maize production: the case of smallholder farmers in Dhidhessa district of Illuababora zone, Ethiopia. J Econ Sustain Dev 5(12):274-284

Tesfa T, Bayu W, Gashaw A, Beshir H (2017) Spice production, marketing, and utilization in South Wollo, Ethiopia. East Afr J Sci 11(1):27-36

Teshome W, Anshiso D (2019) Assessment of production and utilization of black cumin (Nigella sativa) at the Oromia Regional State, Ethiopia. Asian J Agric Extens Econ Sociol, pp 1-12

Verma VK, Kumar P (2015) Marketing behaviour of cumin in Jodhpur district of Rajasthan. Econ Aff 60(1):137

Vijayalaxmi H, Sreepada H (2014) An economic overview of ginger production in Ethiopia. Int J Sci Res 3(12):2052-2054

Wassihun AN, Koye TD, Koye AD (2019) Analysis of technical efficiency of potato (Solanum tuberosum L.) production in Chilga District, Amhara National Regional State, Ethiopia. J Econ Struc 8(1):34

Yosef HH (2008) Effect of high levels of nitrogen and phosphorus fertilizer on growth, yield and yield components of Nigella sativa L. Horticulture Department College of Agriculture, Duhok University, Iraq. Mesopotamia J Agric 36:1

\section{Publisher's Note}

Springer Nature remains neutral with regard to jurisdictional claims in published maps and institutional affiliations.

\section{Submit your manuscript to a SpringerOpen ${ }^{\circ}$ journal and benefit from:}

- Convenient online submission

Rigorous peer review

Open access: articles freely available online

- High visibility within the field

Retaining the copyright to your article

Submit your next manuscript at $\boldsymbol{\Delta}$ springeropen.com 